\title{
The Impact of Exchange Rate Expectations and Interest Rate Differentials on Trade in South Africa: An Econometric Analysis
}

\author{
Innocent Sitima \\ University of Fort Hare, Alice, South Africa \\ innositima@gmail.com, \\ Clifford Kendrick Hlatywayo \\ University of Fort Hare, Alice, South Africa \\ vakendie@gmail.com
}

Doi:10.5901/mjss.2014.v5n2p671

Abstract

This study analyses the impact of exchange rate expectations and interest rate differentials between South Africa and its major trading partners and its effects on trade balances and employment in the exporting sector employment, using quarterly South African data covering the period 1977 to 2008. An empirical model linking the real exchange rate and interest rate differential is instigated to its theoretical determinants is then specified. The study utilizes the VECM methodology to provide both the long run and short run dynamic effects on the trade balance movements. Variables under investigation, (TOT, REER, IR, and IRS) were found to be statistically significant with the trade balance. The VECM model found 3 cointegrating equations and the most interesting result that came from this analysis is the co-movements of real effective exchange rate and interest rates differentials among the 3 cointegrating equations.

Keywords: VECM; Trade balance; Real Effective Exchange Rate; Interest rate differentials

\section{Introduction}

In international economics, exchange rate economics plays a vital role in the economics as it describes and investigates the factors which determine the real exchange rate (RER) ${ }^{1}$ and those that affect its volatility. Arnold (2005) defines the exchange rate simply as the price of one currency in terms of another currency. Mussa (1986), Ghura and Grennes (1993), Golub (1994), MacDonald and Ricci (2003), Kalra (2005), Faure (2006), and Sekantsi (2008), show that most developing economies have experienced high real exchange rate volatility. Moreover this translates into a high degree of uncertainty for the two main monetary policy objectives that policymakers often seek to achieve: price stability and economic growth. Volatile real exchange rates are associated with unpredictable movements in the relative prices in the economy (Al Samara, 2009). Therefore, exchange rate stability is one of the main factors that promote investment, price stability and stable economic growth.

Most world trade currently, with the exception of monetary union such as the European Union, takes place with flexible exchange rates where market pressures have allowed it to generate large fluctuations in currency values. Governments may intervene to move the exchange rate so as to affect trade flows, secondly governments often pursue "dirty" floating so as to affect domestic inflation and to prevent depreciation of a currency, with the aim of preventing import prices from rising, thereby slow inflation, finally the governments may intervene due to the belief that many capital flows represent merely unstable expectations and that the induced movements in exchange rate may cause unnecessary changes in domestic output (Dornbush \& Fisher, 1994).

Through the monetary policy rising interest rate ceteris paribus affects both trade balances and the exchange rate since raising domestic interest rate should strengthen the rand by attracting more capital. However under volatile rates the market weighs the advantages of high interest rate against the downward risk of the exchange rate, and on the whole high interest rate seems to be the reflection of certain fundamental economic weaknesses (scarcity of capital, high inflation) (Potgieter, Falken, Kok, Van Ettinger, 1991).

${ }_{1}^{1}$ Real exchange rate (RER) is the ratio of goods that can be bought in South Africa to goods in the United states (Barro R.A 2008: 441). 
Dornbush, et al., (1994) suggested that high interest rates makes the country less competitive on world markets and therefore tend to cause deterioration in the current account. For various reasons, the exchange rate, however, quite often either "overshoot" or "undershoot" the level indicated by interest rate differentials.

The South African Reserve Bank (SARB) is in charge for the formulation of monetary policy and is co-responsible for the formulation of exchange rate policy and is basically responsible for the implementation of such policies (SARB, 2011). South Africa at present (2013), has a unitary exchange rate system where the value of the rand is fundamentally determined by the market forces of supply and demand. The SARB does not intervene in the foreign exchange market to support the value of the rand. It does, on the other hand, depending on the circumstances in the foreign exchange market, from time to time buy foreign exchange from the market to make the official foreign exchange reserves. The SARB, is in line with its inflation targeting monetary policy framework, has no intermediate policy target or guiding principle regarding the level of exchange rate and remains devoted to allowing the value of the rand to be determined by the market (SARB, 2011).

Since the beginning of 2000 , South Africa adopted on inflation targeting regime, which gives an anchor for inflation expectations but there is no similar policy determined that focuses on exchange rate expectation, since there is no official exchange rate target under freely floating exchange rates.

Historically many countries including South Africa have practiced so- called 'dirty' floating by intervening in the exchange rate market in order to reduce the fluctuations in the exchange rate. The South African economy was characterized with the rand crisis in 2001 and 2002 where the rand depreciated and caused detrimental effect to the economy. These effects were mainly felt in the manufacturing industries in the importing and exporting sector. The South African Reserve Bank (SARB) reacted to the changes through cutting interest rate by 50 basis points resulting in the rand gaining 20 percent in value and a positive change in both trade figures and employment. The exchange rate is usually controlled over few years by relying on 'sterlized' foreign exchange rate market interventions where the central bank buys and sells foreign exchange without the interest rate (Sorensen and Whitta- Jacobsen, 2005).

The main objective of the study is to test the relationship between exchange rate expectations and interest differentials under a flexible exchange rate regime. The sub objective of the study are to examine how the level of the domestic interest rate above foreign interest rate of its major trading partner, the domestic currency will either appreciate, or vice versa; and to examine the interest rate differential on indexed and none indexed bonds in South Africa as well as to look at the trend in exchange rate and trade figures for the past 10 years.

\section{Theoretical Literature}

There are many theories that try to explain the impact of the exchange rate on exports growth such as Obstfeld - Rogoff two country model variant, Jorgensen model and the Sorensen \& Whitta - Jacobsen AS - AD open economy model.

In order to analyze whether weakening the South African rand exchange would raise economic growth sustainability it is important to derive the economic relationships prevailing under flexible exchange rate regimes. It is of paramount importance to be able to derive the AS - AD model for an open economy (Sorensen \& Whitta-Jacobsen, 2005) to highlight the characteristics of alternative exchange rate regime.

Sorensen and Whitta-Jacobsen (2005) provides a good starting point in analyzing the impact of depreciating the rand on export growth and job creation. Their model tries to explain the South African economy in the sense that it assumes that the country in question is using inflation targeting monetary framework. In this regard the inflation targeting framework acts as a nominal anchor. The crucial characteristic of flexible exchange rate regime is that it allows the domestic central bank in this case the South African Reserve Bank (SARB there on) to pursue its own monetary policy even if there is capital mobility. Using the uncovered interest rate parity, nominal exchange rate, $E$, is the number of domestic currency needed to buy one unit of the foreign currency.

$1+i=\left(1+i^{f}\right)\left(E_{e+1} / E\right)$

If $i$ is the domestic nominal interest rate and $i^{f}$ being the foreign nominal interest and $E$ being the spot exchange rate in the period and $E_{+1}$ being the exchange rate in the next period.

Introducing natural logarithm on both sides and the approximation $\operatorname{In}(1+x) \sim x$ then

$i=\left(i^{f}+e_{+1}^{e}-e, e=\operatorname{InE}, e_{+1}^{e}=I n E_{+1}^{e}\right.$

Real exchange rate $E^{r}$ can be defined as:

$E^{r}=\left(E P^{f} / P\right)$

Where $P^{f}$ is the price of foreign goods denominated in foreign currency; $E P^{f}$ is the price of foreign goods measure in domestic currency. By definition the real exchange rate show the amount of units the domestic good which must be 
given up to buy one unit of foreign good. The higher the real exchange rate the cheaper the local goods compared to foreign products. The terms of trade are given as the inverse of the real exchange rate $\left(\left(1 / E^{r}\right)\right)$.

By introducing natural logarithm both sides:

$$
e=\operatorname{In} E^{r}=e+p^{f}-p, \quad p^{f}=\operatorname{In} P^{f} \quad p=\operatorname{InP}
$$

\subsection{The relationship between trade balance and the real exchange rate}

In the open economy, the condition for equilibrium in the goods market is:

$Y=D+G+N X$

Were $D$ is the total private demand for goods and service in the economy, $G$ is the total public demand for goods and service and $N X$ is the trade balance (exports minus imports).

$N X=X-E^{r} M$

Where the volume of exports, $X$, depends positively on the global competiveness of local producers and $E^{r}$ represent real exchange rates.

The amount of imported foreign supplies will depend negatively on the real exchange rate, since a higher relative value of external goods will reduce local consumer demand for goods, partially because an increase in the price of foreign goods reduces the purchasing power of domestic money income (the income effect), and partially because a higher price of foreign goods encourages the consumer to substitute to domestic goods (the substitution effect). $M=M(E, Y, T, r, \varepsilon)$ Were $M$ varies negatively with $E, T$, $r$ and positively with $Y$ and $\varepsilon$. Therefore:

$N X=X\left(E, Y^{f}\right)-E^{r} M\left(E^{r}, Y, T, r, \varepsilon\right)$

From the above equation in $Y$ or $\varepsilon$ will rise of imports, because an increase in the variables will stimulate total private demand for goods and services.

A crucial question that South Africa is trying to answer is how a change in the real exchange rate will affect trade balance. To investigate this, one can calculate the partial derivative of the NX function with respect to $E^{r}$. $\partial N X / \partial E^{r}=\partial X / \partial E-E^{r} . \partial M / \partial E^{r}-M$

Assuming that the initial equilibrium magnitudes of $X, M$ and $E^{r}$ by $X_{0}, M_{0} a n d E_{0}^{r}$. As a benchmark case the trade balance is initially in equilibrium so that $X_{0}=E_{0}{ }^{r} M_{0}$ by rewriting the above equation then:

$\partial N X / \partial E^{r}=M_{0}\left(\partial X / \partial E^{r} . E_{0}^{r} / X_{0}-\partial M / \partial E^{r} . E_{0}^{f} / M_{0}-1\right) \Leftrightarrow \partial N X / \partial E_{0}^{r}=M_{0}\left(\eta_{x}+\eta_{m-1}\right)$

$\eta_{x}=\partial X / \partial E^{r} . E^{r} / X>0$ and $\eta_{m}=-\partial M / \partial E^{r} \cdot E^{r} / M>0$ where $\eta_{x}$ is the elasticity of exports with respect to the respect to the real exchange rate. $\eta_{\mathrm{m}}$ is the mathematical elasticity with respect to the real exchange rate. The above equation shows that a depreciation of domestic currency that is, a raise in the exchange rate $E^{r}$ will improve the trade balances provided the sum of the elasticities of exports and imports demand is greater than $1 \eta_{x}+\eta_{m}>1$, (Marshall - Lerner condition)( Sorensen \& Whitta-Jacobsen 2005).

\subsection{Aggregate demand in the open economy}

The aggregate demand is given as follows:

$Y=D\left(Y, r, E, E^{r}\right)+N X\left(E^{r}, Y^{f}, Y, G, r, \varepsilon\right)+G$

Real exchange rate $E^{r}$ influences due to the income effect; when price of imports raises relative to local prices, the purchasing power of local incomes is eroded, and this will diminish total private demand for goods because domestic residents become poorer.

\subsection{The good market equilibrium condition}

$$
\begin{aligned}
& y-\bar{y}=\beta_{1}\left(e_{-1}^{r}+\Delta e+\pi^{f}-\pi\right)-\beta_{2}\left(i^{f}-\pi_{+1}^{e}-e-\bar{r}^{f}\right)+\widetilde{z} \\
& \widetilde{z}=\beta_{3}(g-\bar{g})+\beta_{4}\left(y-\bar{y}^{f}\right)+\beta_{5}(\operatorname{In} \varepsilon-\operatorname{In} \bar{\varepsilon})
\end{aligned}
$$

To derive the $A D$ curve under flexible exchange rates using the equation $e_{+1}^{e}-e=i-i^{f}$ and using the fact that $i^{f}-\pi_{+1}^{e}=i^{f}-\pi^{f}=r^{f}$ we get:

$$
y-\bar{y}=\beta_{1}\left(e_{-1}^{r}-\theta^{-1}\left(i-i^{f}\right)+\pi^{f}-\pi\right)-\beta_{2}\left(i-i^{f}+r^{f}-\bar{r}^{f}\right)+\widetilde{z}
$$

The larger the value of $\beta_{1}$, that is, the superior the price elasticities of export and import demand, the stronger the effect of monetary policy through exchange rate channel. By increasing the response of the exchange rate to reduce 
domestic interest rate, by so doing the domestic interest decreases relative to abroad, there is a tendency for the domestic currency to depreciate, this leads to the raise of competitiveness which increases net exports (Sorensen \& Whitta-Jacobsen; 2005).

Salvatore (2007) proposed that the depreciation of the domestic currency should over time result in an increase in exports and a decline in imports, with effect that the domestic currency will start to appreciate again, all other things remaining the same, to a new long run equilibrium level. However, Dornbush (1976) in his theory of exchange rate overshooting, argues otherwise, that the there is a tendency for an exchange rate to overshoot its long-run equilibrium level was first and then return.

In theory, the J-curve effect, imply that the depreciation of the currency will affect the current account by causing a currency account deficit first before it start to improve, however if the deficit is large on the current account of the balance of payments, prices increases would lead to a larger increase in the value of exports, until adjustments could outweigh the effect of the price increases (Van Der Merwe \& Mollentze 2010).

\section{Empirical Analysis}

A number of studies have found a statistically significant relationship between depreciations and increased exports, including Fallon and Da Silva (1994), Tsikata (1999) and Golub (2000). Ghura and Grennes (1993) used a sample of 33 African countries over the period 1972-1987, they found significant negative partial correlations of both real US\$ exchange rate misalignment and instability with various measures of macroeconomic performance especially exports. Basing their research on sub Saharan countries Bleamy and Greanaway (2001) found that real exchange rate volatility has a significant negative impact on investment, and volatility in the terms of trade has a negative impact on growth. Both growth and investment are higher when the terms of trade are more favorable and the real exchange rate is less overvalued. The most amazing feature of the sample is that all countries have experienced considerable real exchange rate depreciation (more than 4\% p.a. on average). Bini-Smaghi (1991) did a study of manufacturing exports and exchange rate for European countries, the results showed that they is a relatively negative impact from volatility for countries that invoice their exports in a currency other than that of their local currency.

The empirical literature on the effect of real exchange rate movements on employment is limited. Branson and Lowe (1988) studied the reaction of US manufacturing employment and output to exchange rate movements. In which the results showed that exchange rate movements were associated with significant output and employment changes. Campa and Goldberg (1998), using two-digit data over a 25 years period, studied the elasticities of employment on permanent changes of exchange rates and found small employment elasticities and relatively larger wage elasticities to permanent exchange rate changes. However, they find only weak correlations between their measure of exposure and the pattern of industry wage-responsiveness. Revenga (1992) used import prices on selected three- and four-digit US manufacturing industries. Concentrating on import-competing industries, she finds larger employment effects. According to her estimates, the 40\%-so real appreciation of the dollar between 1980 and 1985 lowered employment in importcompeting industries by $4.5-7.5 \%$.

Gourinchas (1992) studied the real interest rate response of US manufacturing gross job flows at the four-digit level, with data from the Longitudinal Research Database. Later, Gourinchas (1998) addressed the case of France, for the period 1984-1992. In which he noted a number of important differences such as France is substantially more open than the US and the fact that most French manufacturing industries face major international exposure.

However, some studies, Naude (2002), have established that there is no significant relationship between the real exchange rate and aggregate exports. Bélanger and Gutiérrez (1990) examined studies of floating exchanging rates along with interest rate differentials and found little concrete evidence that exchange rate volatility served as a significant impediment to export development.

\section{Methodology}

The study will estimate the impact of exchange rate expectation and interest rate differential on trade using the VECM model. Using the annual South African data from 1977 to 2008, the model to be estimated is specified as follows:

$$
T B=\beta_{0}+\beta_{1} R E E R+\beta_{2} I R S+\beta_{3} T O T+\beta_{4} U N E M P L+\beta_{5} I R+\mu
$$

Where

TB - the trade balance for all international transactions in South Africa for the period,

IRS - the interest rate differential between South African domestic interest rate and USA interest rate, 
REER- the Real Effective Exchange Rate of the South African Rand,

TOT- Terms of Trade,

IR - the domestic interest rate.

Annual time series data from 1977 to 2008 will be used. The data sources are World Bank WDI/GDF for the trade and USA interest rate data, while the exchange rate data was obtained from IMF IRS, the domestic interest rate data was retrieved from the South African Reserve Bank (SARB) Quarterly Bulletin, all trade data was obtained from the African Development Indicators- World Bank all data was downloaded from the online query Quantec. To avoid spurious regressions this study employs the Augmented Dickey Fuller (ADF) and the Phillip Perron (PP) tests to test for stationarity in the variables of interest. The results for stationarity are presented in table 1 below.

Table 1: Unit Root tests

\begin{tabular}{|c|c|c|c|c|c|c|}
\hline & TB & REER & IRS & TOT & UNEMPL & IR \\
\hline \multicolumn{7}{|c|}{ ADF } \\
\hline Level & -1.2195 & -1.0659 & -2.7531 & -3.2197 & -1.6054 & -3.2300 \\
\hline 1st difference & $-5.7423^{\star \star}$ & $-4.4264^{\star \star}$ & $-6.0686^{\star \star \star}$ & $-4.7233^{\star}$ & $-5.4258^{\star \star}$ & $-3.8373^{\star \star}$ \\
\hline \multicolumn{7}{|c|}{ PP } \\
\hline Level & -1.2381 & -1.2417 & -2.7995 & -2.3605 & -2.0036 & -3.9895 \\
\hline 1st difference & $-5.7485^{\star \star}$ & $-4.3929^{\star \star}$ & $-6.6013^{\star \star \star}$ & $-6.7177^{\star}$ & $-5.6657^{\star \star}$ & $-9.7527^{\star \star}$ \\
\hline${ }^{\star \star \star \star},,{ }^{\star *}$ represent significant levels at 1\%, 5\%, 10\% respectively \\
\hline
\end{tabular}

Table 1 show that all the variables are stationary and the study concludes that the variables are stationary and the problem of "nonsensical" regression based on non- stationary results is mitigated for a proper econometrical estimation of the data.

\section{Empirical Findings and Results}

The common information criteria are the Akaike Information Criteria (AIC), Schwarz Information Criterion (SIC), and Hannan-Quinn Information Criterion (HQI). An optimal lag length suggested by the above information criteria can be chosen as these criteria may sometimes produce conflicting lag length choices. However, decision about the lag structure of the ECM model could be based on the fact that a given criterion produces a white noise residual and conserves degrees of freedom. Table 2 below presents the selection of an optimal lag length for this study.

Table 2: Lag structure criteria

\begin{tabular}{|c|c|c|c|c|c|c|}
\hline Lag & LogL & LR & FPE & AIC & SC & HQ \\
\hline 0 & -1121.574 & NA & $1.79 \mathrm{e}+25$ & 75.17157 & 75.45181 & 75.26122 \\
\hline 1 & -1015.871 & 162.0765 & $1.81 \mathrm{e}+23$ & 70.52476 & $72.48644^{*}$ & 71.15232 \\
\hline 2 & -959.0731 & $64.37144^{*}$ & $6.18 \mathrm{e}+22^{*}$ & $69.13821^{*}$ & 72.78132 & $70.30367^{*}$ \\
\hline
\end{tabular}

* indicates lag order selected by the criterion

LR: sequential modified LR test statistic (each test at $5 \%$ level)

FPE: Final prediction error

AIC: Akaike information criterion

SC: Schwarz information criterion

HQ: Hannan-Quinn information criterion

The selection is made using a maximum of 7 lags, in order to permit adjustment in the model and to accomplish well behaved residuals. Table 2 shows that all with the exception of the SC selected 2 lag for the VAR. The information criteria approach has therefore produced compatible results and a conclusion can be arrived at using this approach only. Having satisfied the assumption of stationarity, the study performs a cointegration tests to determine any long association in the variables for the model and to ascertain the number of cointegrating equations. The cointegration test is conducted in both the trace and the maximum eigenvalue tests. The results are given below in table 3 and table 4 .

Table 3: Conitegration (Trace) test results 


\begin{tabular}{|l|c|c|c|c|}
\hline \multicolumn{1}{|c|}{ No. of CE(s) } & Eigenvalue & Statistic & Critical Value & Prob. $^{* *}$ \\
\hline None * & 0.960202 & 220.0540 & 95.75366 & 0.0000 \\
\hline At most 1 * & 0.859141 & 126.5594 & 69.81889 & 0.0000 \\
\hline At most 2 & 0.768350 & 69.71953 & 47.85613 & 0.0001 \\
\hline At most 3 & 0.542086 & 27.30620 & 29.79707 & 0.0944 \\
\hline At most 4 & 0.127998 & 4.655046 & 15.49471 & 0.8443 \\
\hline At most 5 & 0.023280 & 0.683108 & 3.841466 & 0.4085 \\
\hline $\begin{array}{l}\text { Trace test indicates 3 cointegrating eqn(s) at the 0.05 level } \\
\text { * denotes rejection of the hypothesis at the 0.05 level } \\
\text { ** MacKinnon-Haug-Michelis (1999) p-values }\end{array}$ \\
\hline
\end{tabular}

Table 4: Cointegration Rank (Maximum Eigenvalue) test results

\begin{tabular}{|c|c|c|c|c|}
\hline No. of CE(s) & Eigenvalue & Statistic & Critical Value & Prob.** \\
\hline None * & 0.960202 & 93.49454 & 40.07757 & 0.0000 \\
\hline At most 1 * & 0.859141 & 56.83990 & 33.87687 & 0.0000 \\
\hline At most 2 * & 0.768350 & 42.41333 & 27.58434 & 0.0003 \\
\hline At most 3 * & 0.542086 & 22.65115 & 21.13162 & 0.0303 \\
\hline At most 4 & 0.127998 & 3.971938 & 14.26460 & 0.8623 \\
\hline At most 5 & 0.023280 & 0.683108 & 3.841466 & 0.4085 \\
\hline
\end{tabular}

The trace test indicated 3 cointegrating equations at $5 \%$ level while the maximum eigen value shows that there are 4 cointegrating equations at $5 \%$ significant. Both the trace and the max eigenvalue test indicate that we should reject the null hypothesis of no cointegrating equations. The study uses the results from the trace test solely because it is a stricter test than the eigenvalue test.

The study implements the Vector Error Correction model with 2 lags and 3 cointegrating equations. The main advantage of the VECM is that it allows the model to distinguish between long run and short run dynamics of the model. The results of the long run dynamics are tabulated as well as the long run cointegrating equations are represented as table5 and equations 1, 2, 3 below:

Table 5: Long run Cointegrating equations results

\begin{tabular}{|l|c|c|c|}
\hline \multicolumn{1}{|c|}{ Variable } & coefficient & Standard error & t- statistic \\
\hline TB(-1) & 1.0000 & - & - \\
\hline TOT(-1) & - & 1.0000 & - \\
\hline UNEMPL(-1) & - & - & 1.0000 \\
\hline & $-2.03 \mathrm{E}+09$ & 1.8733 & 0.5596 \\
REER(-1) & $(2.8 \mathrm{E}+08)$ & $(0.279)$ & $(0.059)$ \\
& {$[-7.328]$} & {$[6.707]$} & {$[9.458]$} \\
\hline & $3.00 \mathrm{E}+10$ & -29.152 & -5.1099 \\
IR(-1) & $(3.2 \mathrm{E}+09)$ & $(3.232)$ & $(0.684)$ \\
& {$[9.339]$} & $-9.019]$ & {$[-7.462]$} \\
\hline \multirow{3}{*}{ IRS(-1) } & $-2.48 \mathrm{E}+10$ & 27.856 & 4.1709 \\
& $(4.2 \mathrm{E}+09)$ & $(4.254)$ & $(0.901)$ \\
\hline C & {$[-5.878]$} & {$[6.547]$} & {$[4.627]$} \\
\hline Standard errors in () \& t-statistics in [] & -272.82 & -71.675 \\
\hline
\end{tabular}

$T B=1.60-2.03 R E E R+3.00 I R-2.48 I R S$

$T O T=-272.82+1.873 R E E R-29.152 I R+27.856 I R S$

$U N E M P L=-71.675+0.5596 R E E R-5.1099 I R+4.1709 I R S$

The long run cointegrating equations for the regression analysis shows that real effective exchange rate (REER), Interest rate differentials (IRS), and domestic Interest rate (IR) affect trade balances (TB), Terms of Trade (TOT), and 
Unemployment (UNEMPL) in the long run. Equation 1, shows that there is a negative relationship between trade balance and the exchange rate and interest rate differentials, 1 basis point change in REER causes 2.03 basis points decrease in trade balances while a 1 basis point change in interest rate differential causes TB to lose by 2.48 . This means that when the rand deprecates the trade balances fall because it will be cheaper to import than to export. A negative interest rate differentials between South Africa and is major partner USA results in higher imports than exports and hence a negative trade balance. However an increase in domestic interest rate increase trade balances due to the influx of foreign capital, this allows domestic production to increase the result is more exports.

The second cointegrating equation shows REER, IR, and IRS also affect the terms of trade in South Africa. The equation shows that there is a positive relationship between TOT and REER and IRS, the results are in line with economic theory that Terms of trade if the Rand has more purchasing power then the terms of trade will improve. The positive interest rate differential allows South Africa to have a comparative advantage in the world markets this result in more exports than imports.

The third cointegrating equation show that UNEMPL and REER, IR, IRS are related in the long run. There is a positive relationship between UNEMPL, REER, and IRS; a positive REER causes an increase in unemployment in South Africa because a strong rand results in low exports. South Africa is predominantly a manufacturing country, when the rand appreciates less goods are exported and this results in more people being laid off from work. Positive interest rate differentials entail that domestic goods will be expensive on the international frontier, thereby causing high unemployment in the local industries, however low domestic interest rate reduces unemployment.

The short run dynamics of the model are given as table 6 :

Table 6: Error Correction results

\begin{tabular}{|c|c|c|c|}
\hline Variable & Coefficient & Standard error & $\mathrm{t}$ - statistics \\
\hline CointEq1 & -0.392385 & $(0.11631)$ & {$[-3.37355]$} \\
\hline CointEq2 & $-2.29 \mathrm{E}+08$ & $(1.2 \mathrm{E}+08)$ & {$[-1.92053]$} \\
\hline CointEq3 & $-8.65 \mathrm{E}+08$ & $(2.9 \mathrm{E}+08)$ & {$[-2.96275]$} \\
\hline $\mathrm{D}(\mathrm{IRS}(-1))$ & 1.4009 & $(5.0 \mathrm{E}+08)$ & {$[2.80557]$} \\
\hline $\mathrm{D}(\mathrm{TB}(-2))$ & 0.437533 & $(0.23102)$ & {$[2.89391]$} \\
\hline $\mathrm{D}(\mathrm{TOT}(-1))$ & $-2.92 \mathrm{E} 08$ & $(1.6 \mathrm{E}+08)$ & {$[-3.81659]$} \\
\hline
\end{tabular}

The error correction results and the short run given in table 6 above shows that policies aimed at IRS, TB, and TOT will have beneficial effects in the short run. Table 6 shows 1 basis point change in the interest rate differentials (IRS) will causes a 1.40 increase in trade balances in the short run. Trade balances from the previous period affect the current period while TOT has a negative effect in the short run.

The study acknowledge the major problem of any econometric procedure is on how best to control the overall probability of rejecting the model when its true and multiple test statistics are used. The study adopts various diagnostic tests on the coefficient, residual and stability diagnostics on the model. The proposed testing procedure of applied econometric tests is applied to test for serial correlation in an observed time series, for normality, and significance of coefficient in a dynamic regression model (King, Zhang \& Akran, 2007). The diagonistic tests are represented in table 7 show that there is no serial correlation, there is no conditional Heteroscedastic, and the model is normally distributed.

Table 7: Diagnostic checks

\begin{tabular}{|l|l|c|c|}
\hline \multicolumn{1}{|c|}{ Test } & \multicolumn{1}{c|}{ Null hypothesis } & t- statistic & probability \\
\hline Lagrange Multiplier (LM) & No serial correlation & 36.84471 & 0.4296 \\
\hline Jarque- Bera (JB) & There is Normality & 11.29027 & 0.5042 \\
\hline White (CH- sq) & No conditional Heteroscedasticity & 43.59056 & 0.1799 \\
\hline
\end{tabular}

As noted by Blanchard (1987), the study employs the Impulse response and the variance decomposition which provides some powerful and useful econometric inferences about the whole system of the model (Murwirapachena et al., 2013). Table 8 shows the Variance decomposition for 10 years for all the variables in the model.

Table 8: Variance Decomposition of Trade Balances 


\begin{tabular}{|c|c|c|c|c|c|c|c|}
\hline Period & S.E. & TB & TOT & UNEMPL & REER & IR & IRS \\
\hline 1 & $1.59 \mathrm{E}+09$ & 100.0000 & 0.000000 & 0.000000 & 0.000000 & 0.000000 & 0.000000 \\
\hline 2 & $2.64 \mathrm{E}+09$ & 82.27877 & 6.111495 & 5.235795 & 2.347630 & 0.648970 & 3.377341 \\
\hline 3 & $3.60 \mathrm{E}+09$ & 69.94635 & 16.05794 & 2.839865 & 5.927601 & 0.424419 & 4.803829 \\
\hline 4 & $4.57 \mathrm{E}+09$ & 68.89598 & 16.05024 & 2.300944 & 8.126972 & 0.327041 & 4.298816 \\
\hline 5 & $5.52 \mathrm{E}+09$ & 68.81055 & 17.02195 & 1.990662 & 8.025990 & 0.253075 & 3.897778 \\
\hline 6 & $6.29 \mathrm{E}+09$ & 71.01694 & 16.41242 & 1.611832 & 7.677646 & 0.207374 & 3.073787 \\
\hline 7 & $6.97 \mathrm{E}+09$ & 71.84188 & 16.68308 & 1.536889 & 7.126719 & 0.209691 & 2.601735 \\
\hline 8 & $7.65 \mathrm{E}+09$ & 72.83990 & 15.85540 & 1.546060 & 7.327969 & 0.213764 & 2.216904 \\
\hline 9 & $8.39 \mathrm{E}+09$ & 72.95337 & 15.27307 & 1.612323 & 7.864841 & 0.201072 & 2.095324 \\
\hline 10 & $9.06 \mathrm{E}+09$ & 72.95517 & 14.92134 & 1.542985 & 8.270304 & 0.183876 & 2.126318 \\
\hline
\end{tabular}

Trade Balance explains itself 100 percent in the first period, while in the $5^{\text {th }}$ period only approximately 68 percent is explained by Trade Balances and 17 percent is explained by TOT and the remainder is explained by UNEMPL, REER, IR, and IRS. The impulse response is given by figure 1 below. The figure shows the dynamic response of Trade Balances to one standard deviation innovations of the system. It shows both direction and persistence of the variables. A one period shock to UNEMPL, REER, IR, and IRS marginally appreciates trade balances but quickly dies off in period 8 to 9 . However a one-period standard deviation in TB will cause a persistent for all 10 periods.

Figure 1: Impulse response of Trade Balance

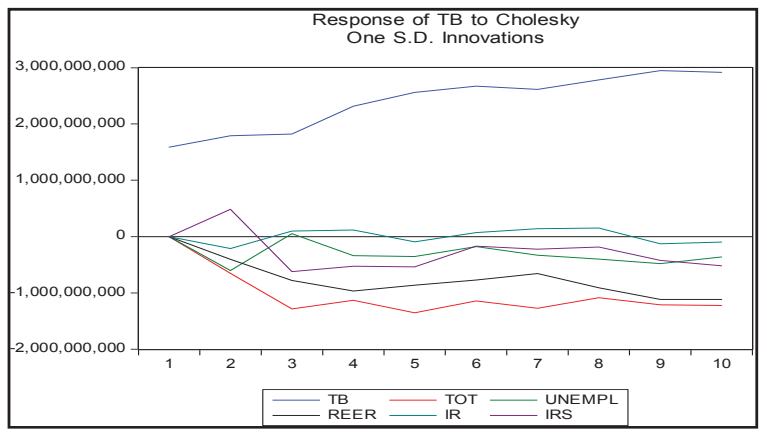

\section{Conclusion}

The purpose of this study was to investigate whether there is a link between real effective exchange rates and interest rate differentials to influence trade balances and other macroeconomic variables such interest rate, terms of trade, and unemployment in South Africa in period 1977-2008. In this study theoretical and empirical literature was assessed. Annual time series data for the period 1977-2008 was used for the purpose of running the regressions. The regression method used to estimate the models is the VECM method. The results showed that South Africa is a predominantly exporting country with most of its exports are in the agro- processing industry and most of its exports are relatively inelastic on the world market.

The results of this study also presented exciting research opportunities, not only for future exchange rate studies but also for explorative analysis into the relationship in other variables. For future researches the study acknowledges that the methodology used in this research can be enhanced by using other methodologies such as the ARCH, ARIMA or $\mathrm{GARCH}$. Future research can incorporate other variables and also use other data frequency such as monthly or daily that can enhance the study of the exchange rates and interest rate differentials.

\section{References}

Al Samara, M. (2009). Exchange rate pass- through: Evidence from the Syrian Economy. International Economics and Policy, 10, 405425.

Anorld, R.A. (2005). Macroeconomics. ( $7^{\text {th }}$ ed). Mason; Thompson Western.

Bini-Smaghi L. (1991). Exchange rate variability and trade: why is it so difficult to find any empirical relationship? Applied Economics, 23, 
927-936.

Branson, W., and Lowe J. (1988). Exporting jobs? The impact of import competition on employment and wages in U.S Manufacturing. Quarterly journal of economics, 107, 255-284.

Campa, J., and Goldberg, L. (1998). Employment versus wage adjustment and the U.S. dollar. Working paper \#6749, NBER, Cambridge, MA, October.

Dornbusch, R. (1975). Exchange rates and fiscal policy in a popular model of international trade, American Economic Review, 65, 859871.

Dornbush, R. (1976). 'Expectations and Exchange Rate Dynamics', Journal of political economy, 84.

Elbadawi, I.A. (1994). "Estimating Long-Run Equilibrium Exchange Rates" in Wiliamson, John, (eds), Estimating Equilibrium Exchange Rates. Institute for International Economics, Washingnton DC.

Fallon, P., and Pereira de Silva, L. (1994). "South Africa: Economic performance and policies." World Bank Informal Discussion Papers on Aspects of the South African Economy no. 7, The Southern Africa department, The World Bank.

Faure A. P. (2006). The Foreign Exchange Market. Quoin Institute (pty) Itd. Cape Town.

Ghura, D. and Grennes T.J. (1993) "The Real Exchange Rate and Macroeconomic Performance in Sub-Saharan Africa", Journal of Development Economics, 42, 155-174.

Golub, S.S., and Ceglowski, J. (2002). "South African Real Exchange rates and Manufacturing Competitiveness." South African Journal of Economics, 70, 1047-1075.

Gourinchas, P.O. (1998). Exchange rates and jobs: What do we learn from gross flows? NBER Macroeconomics Annual, forthcoming.

Gourinchas, P.O. (1999). Exchange rates do matter: French job reallocation and exchange rate turbulence, 1984-1992. European Economic Review, 43, 1279-1316

Kalra S. (2005). How stable is the demand for money in emerging economies? Journal of Applied Economies, 42,3307 -3318

King M.L., Zhang X., and Akrama M. (2007). A new procedure for multiple testing of econometric models. Monash university papers

MacDonald, R., and Ricci. L.A. (2003). Estimation of the real exchange rate for South Africa. IMF working paper

Murwirapachena G, Chigona I and Maredza A. (2013). Fiscal Policy and Unemployment in South Africa: 1980- 2010. Mediterranean Journal of Social Sciences, 4, 579- 587.

Mussa, P. (1986). "Nominal Exchange Rate Regimes and the Behavior of Real Exchange Rates: Evidence and Implications," Carnegie Rochester Conference Series on Public Policy 25.

Naudé, W. A. (2000). "The Determinants of South African Exports: An Econometric Analysis." South African Journal of Economics, 68 , 246-265.

Potgieter, W., Falken, H.B., Kok W.J., and Van Ettinger M.C.C. (1991). Financial institutions. Oxford press. Cape Town.

Revenga, A., (1992). Exporting jobs? The impact of import competition on employment and wages in U.S. manufacturing. Quarterly Journal of Economics, 107, 255-284

Salvatore, D. (2007). International Economics. Hoboken: John Wiley \& sons.

Samson, M., Ampofo, S., Mac Quene K., Ndebele, A. and Van Niekerk., I. (2003). The volatility of the rand and its impact on the manufacturing sector: the impact on exporters and investors. Economic Policy Research, 35. Cape Town.

SARB, (2011): Dates of change in the repurchase rate. [Online]. Available: http://www.reservebank.co.za/internet/Historicdata.nsf /Mainpage?OpenPage\&Click=42256DA4002CFF0E.29d44b91ee5b4df442256d860053d613/\$Body/0.AFC [Accessed 13 July 2013].

Sekantsi L. (2008). The impact of real exchange rate volatility on S.A exports to the U.S: Bounded test approach. South African Journal of Economics, 41, 36-42.

Sorensen, P.B., and Whitta-Jacobsen, J.H. (2005). Introducing Advanced Macroeconomics: Growth and Business cycles. Berkshire. McGraw-Hill Education.

Stockman, A.C. (1983). "Real Exchange Rates under Alternative Nominal Exchange-Rate Systems," Journal of International Money and Finance, 22, 120-45.

Tsikata, Y. (1994). "Determinants of Exports and Imports of Manufactured Goods in South Africa." In Fallon, P. \& Pereira de Silva, L.A. 1994. "South Africa: Economic Performance and Policies." Discussion Paper 7, World bank Southern African Department.

Van Der Merwe, E., and Mollentze, S. (2010). Monetary Economics in South Africa. Oxford University Press Southern Africa; Cape Town 
